\title{
UNDERGRADUATE STUDENTS' KNOWLEDGE ON TEMPOROMANDIBULAR DISORDERS IN CROATIA
}

\author{
Tomislav Badel ${ }^{1}$, Ivona Bago Jurič $\check{c}^{2}$ Vesna Fugošićc ${ }^{3}$ Ivan Zajc ${ }^{4}$, \\ Andreja Carek $^{5}$ and Dijana Zadravec ${ }^{6}$ \\ ${ }^{1}$ Department of Removable Prosthodontics, ${ }^{2}$ Department of Endodontics and Restorative Dentistry, \\ School of Dental Medicine, University of Zagreb, Zagreb; ${ }^{3}$ Department of Prosthodontics, \\ Department of Dental Medicine at School of Medicine, University of Rijeka, Rijeka; \\ ${ }^{4}$ Department of Oral and Maxillofacial Surgery, ${ }^{5}$ Department of Fixed Prosthodontics, \\ School of Dental Medicine, University of Zagreb; ${ }^{6}$ Department of Diagnostic and Interventional Radiology, \\ Sestre milosrdnice University Hospital Centre, University of Zagreb, Zagreb, Croatia
}

SUMMARY - The aim of this study was to evaluate Croatian undergraduate students' knowledge based on what they learned in the recent course, as well as the students' own judgment and opinions about geriatric dentistry education concerning temporomandibular disorders (TMDs) of the elderly. The study was carried out by means of a questionnaire administered in the last study year to students of the School of Dental Medicine, University of Zagreb and students of the Department of Dental Medicine at the School of Medicine, University of Rijeka. The questionnaire included questions about relevant specific knowledge on TMD, and statements related to their own opinion about geriatric dentistry education received during the study. Regarding students' knowledge related to TMDs, students from Rijeka gave more positive answers $(\mathrm{p}=0.012)$. Students from Rijeka gave more positive answers regarding physical therapy for treatment of TMD ( $\mathrm{p}=0.004)$ and disc displacement and osteoarthritis as the most common disorders of the temporomandibular joint $(\mathrm{p}=0.031)$. Students from Zagreb were more unsatisfied with the skills in the field of geriatric dentistry (disagreed 57.45\%) than students from Rijeka (45.83\% had neutral standpoint and $37.50 \%$ agreed $)(p=0.005)$. The level of the participants' knowledge pointed to the need of improving undergraduate dental teaching about the specific geriatric education, including knowledge about TMD.

Key words: Students; Croatia; Geriatric dentistry; Osteoarthritis; Temporomandibular joint disorders; Education, dental

\section{Introduction}

Geriatric dental education was defined as the portion of the predoctoral dental curriculum that deals with special knowledge, attitudes, and technical skills required in the provision of oral health care to older adults, according to Mohammad et al. ${ }^{1}$. Besides general medicine, this includes additional specialized

Correspondence to: Andreja Carek, DDM, PhD, School of Dental Medicine, University of Zagreb, Gundulićeva 5, HR-10000

Zagreb, Croatia

E-mail: acarek@sfzg.hr

Received December 28, 2016, accepted July 12, 2017 knowledge such as temporomandibular disorders (TMDs), an umbrella term for certain myogenic and arthrogenic diagnoses ${ }^{2,3}$.

Musculoskeletal disorders are typical of old age, and there is no doubt that aging affects the structure and function of temporomandibular joints $(\mathrm{TMJs})^{4}$. TMDs as the orofacial form of these musculoskeletal disorders are not the most common group of diseases in geriatric dentistry practice, unlike problems related to restorative dentistry, especially prosthodontics ${ }^{5,6}$. The clinical picture of TMJ functional disturbances may range from physiological variability of joint structure functioning (sometimes painless joint sound) to 
painful condition with pronounced clinical signs of TMJ disorder ${ }^{7-10}$. The psychological factor in musculoskeletal diseases, differential diagnosis of orofacial pain, and chronic systemic diseases and medications used in the treatment should be taken into account ${ }^{11,12}$.

The aim of this study was to identify the status of geriatric dentistry education at two Croatian schools. For this purpose, the undergraduate students' knowledge based on what they learned in the recent course, as well as the students' own judgment and opinions about geriatric dentistry education concerning oral care and TMDs of the elderly was evaluated.

\section{Materials and Methods}

The study was carried out in 71 undergraduate students (mean age 23.8 years; 29 male and 42 female), of which 47 students ( 18 male and 29 female) were from the School of Dental Medicine, University of Zagreb, and 24 students (11 male and 13 female) from Dental Department, School of Medicine, University of Rijeka, attending the last year of their dental education. Not including the complete number of students having participated in this study can be seen as a relative limitation of the results obtained because the total sample taken from both institutions amounted to approximately $40 \%$ of the overall number of students. The sample was collected at a practical course when all the students attending the course were interviewed.

Participants were personally informed about the purpose of the study and contents of the questionnaire, and they gave their written consent for participation. However, the questionnaires did not include collecting personal data that could subsequently be used to identify individual study participants. Student participation was completely voluntary and the total number of participants was collected in the interviewed groups according to their schedule and without leaving anyone out, if they may have not wished to participate in the study. Gender disproportion in the study sample was the consequence of a smaller quota of dental students in Rijeka, with a disproportionally greater number of females compared to the larger student quota in Zagreb. Due to the greater absolute number of students in Zagreb, there was a relatively larger share of male students across all study years. The study was ap- proved by the Ethics Committee of the School of Dental Medicine, University of Zagreb.

The self-administered questionnaire used in the study consisted of four general questions: university attended, student's gender, and age and duration/years of studying. The main part of the questionnaire were 6 questions about oral health and oral care in the elderly, and the next 20 questions were about the level of relevant specific knowledge on TMD, that is, desirable knowledge according to the currently generally accepted guidelines on the management of TMD patients. Students' knowledge was based on what they had learned in the recent course attended in their study. The offered answers to these questions were: 'yes', 'no', and 'do not know'.

The last eight statements were related to their own opinion about geriatric dentistry education received during the study. Students were asked to indicate their agreement with each statement on an 11-point scale, where 0-3 means 'disagree', 7-10 means 'agree', and 4-6 means 'neutral standpoint' ${ }^{\text {' }}$.

Various types of the answers offered (straight answers, i.e. using the 11-point scale) were chosen to reveal the nuances of knowledge levels that were not completely limited to geriatric dentistry. Teachers and associates from the course of Prosthodontics, particularly those sub-specialized in TMD management, helped in pre-testing of certain questions and their definitive wording in the final version of the questionnaire. For each question, an expert consensus was reached by their filling out the questionnaire and working on certain questions until they were clear and unambiguous. Since the questions were clearly defined, the consensus was reached after revision of three questions and agreeing on their final version that was included in the questionnaire.

The validity of the test was evaluated in two different periods (2-3 days after the first answering the questions) in 6 students from Rijeka and 12 students from Zagreb, and each student was allocated a doubledigit identification number to remember. The intraexaminer reliability was the mean value of Cohen's kappa index 0.93 for all questions in the questionnaire.

Statistical analysis was performed by using the Statistica software (StatSoft Inc., Tulsa, USA). Different non-parametric analytical procedures were used, as well as t-test, and $\chi^{2}$-test or Fisher exact test ${ }^{14}$. 
Table 1. Questions related to knowledge about oral care in the elderly

\begin{tabular}{|c|c|c|c|c|}
\hline Question & $\begin{array}{l}\text { School of } \\
\text { Dentistry }\end{array}$ & Yes, n (\%) & No, n (\%) & $\begin{array}{l}\text { Do not know, } \\
\mathrm{n}(\%)\end{array}$ \\
\hline \multirow{2}{*}{$\begin{array}{l}\text { 1. Does the share of older people within the general } \\
\text { population continue to increase?* }\end{array}$} & Zagreb & $43(91.49 \%)$ & $1(2.13 \%)$ & $3(6.38 \%)$ \\
\hline & Rijeka & $17(70.83 \%)$ & & $7(29.17 \%)$ \\
\hline \multicolumn{5}{|l|}{ Fisher exact test: $\mathrm{p}=0.0252^{*}$} \\
\hline \multirow{2}{*}{$\begin{array}{l}\text { 2. Is the need for health care of the elderly becoming } \\
\text { a major public health issue? }\end{array}$} & Zagreb & $43(91.49 \%)$ & $1(2.13 \%)$ & $3(6.38 \%)$ \\
\hline & Rijeka & $19(79.17 \%)$ & $1(4.17 \%)$ & $4(16.67 \%)$ \\
\hline \multicolumn{5}{|l|}{ Fisher exact test: $\mathrm{p}=0.2447$} \\
\hline \multirow{2}{*}{$\begin{array}{l}\text { 3. Is geriatric dentistry a multidisciplinary dental branch } \\
\text { closely related to public health? }\end{array}$} & Zagreb & $35(74.47 \%)$ & $3(6.38 \%)$ & $9(19.15 \%)$ \\
\hline & Rijeka & $19(79.17)$ & $2(8.33 \%)$ & $3(12.50 \%)$ \\
\hline \multicolumn{5}{|l|}{ Fisher exact test: $\mathrm{p}=0.8237$} \\
\hline \multirow{2}{*}{$\begin{array}{l}\text { 4. Are prosthodontics and implant prosthodontics } \\
\text { the bases of geriatric dentistry due to the high share } \\
\text { of prosthodontic patients in this age group? }\end{array}$} & Zagreb & $38(80.85 \%)$ & $1(2.13 \%)$ & $8(17.02 \%)$ \\
\hline & Rijeka & $20(83.33 \%)$ & & $4(16.67 \%)$ \\
\hline \multicolumn{5}{|l|}{ Fisher exact test: $\mathrm{p}=1.000$} \\
\hline \multirow{2}{*}{$\begin{array}{l}\text { 5. Do health problems, social isolation, economic } \\
\text { and other individual factors increase the risk of } \\
\text { hindering geriatric population in receiving health care? }\end{array}$} & Zagreb & $38(80.85 \%)$ & & $9(19.15 \%)$ \\
\hline & Rijeka & $16(66.67 \%)$ & $2(8.33 \%)$ & $6(25.00 \%)$ \\
\hline \multicolumn{5}{|l|}{ Fisher exact test: $\mathrm{p}=0.1009$} \\
\hline \multirow{2}{*}{$\begin{array}{l}\text { 6. Does the prevalence of rheumatologic diseases increase } \\
\text { in elderly population? }\end{array}$} & Zagreb & $40(85.11 \%)$ & & $7(14.89 \%)$ \\
\hline & Rijeka & $20(83.33 \%)$ & & $4(16.67 \%)$ \\
\hline \multicolumn{5}{|l|}{ Fisher exact test: $\mathrm{p}=1.000$} \\
\hline
\end{tabular}

*with significance between students of dental medicine from Zagreb and Rijeka

\section{Results}

A high percentage of students (students in total/ subgroup of students from Rijeka/subgroup of students from Zagreb) gave positive answers (80.56\%/ $77.08 \% / 84.04 \%$, respectively) to the questions about oral health and oral care of the elderly (Table 1$)$; there was no statistically significant difference $\left(\chi^{2}\right.$-test: df69 $=0.4807 ; \mathrm{p}=0.3161)$. There was no statistical significance $\left(\chi^{2}\right.$-test: df69=0.0894; $\left.p=0.4645\right)$ concerning the answer 'I do not know' when comparing the percentages of answers $(15.03 \% / 19.45 \% / 12.77 \%$, respectively). Negative answers represented the lowest share (2.5\%/2.13\%/3.48\%, respectively), which was not statistically significant ( $\chi^{2}$-test: $d f 69=0.0894 ; p=0.4645$ ).

Regarding the main group of statements (Table 2) related to TMDs, there was difference in answers to particular questions between students from the two universities (Table 2, marked with *). Students in total/ students from Rijeka/students from Zagreb provided the answer 'yes/I do not know/no' at the mean rate of $64.72 \% / 22.89 \% / 11.55 \%$, respectively. Students from
Rijeka and those from Zagreb gave the following percentage of answers: $71.67 \% / 18.54 \% / 9.79 \%$, and $61.17 \% / 25.12 \% / 12.44 \%$, respectively. Comparison of the share of positive answers to the questions between the students in total and the two Croatian Schools of Dental Medicine showed that the students from $\mathrm{Ri}$ jeka provided more positive answers, which was statistically significant ( $\chi^{2}$-test: df69=2.3231; $\mathrm{p}=0.0116$ ). More students from Zagreb answered 'I do not know' but it was at the border of statistical significance $\left(\chi^{2}-\right.$ test: df69=1.6235; $\mathrm{p}=0.0545)$. There was no statistically significant difference concerning negative answers $\left(\chi^{2}\right.$-test: df69=0.7360; $\left.p=0.2321\right)$.

Students from both subgroups had the lowest mean value in answers to the questions related to gerodontology as a specialized field and the level of their own education, i.e. score 5.54 on the 11-point scale (Table 3). There were some statistically significant differences between the subgroups of students $\left(\chi^{2}\right.$-test: $\mathrm{df} 2=7.4990$; $\mathrm{p}=0.024$ ) regarding the opinion on the need for subspecialization or postgraduate education in the field of ger- 
Table 2. Statements about knowledge on temporomandibular disorders

\begin{tabular}{|c|c|c|c|c|}
\hline Question & $\begin{array}{l}\text { School of } \\
\text { Dentistry }\end{array}$ & Yes, n (\%) & No, n (\%) & $\begin{array}{l}\text { Do not know, } \\
\mathrm{n}(\%)\end{array}$ \\
\hline \multirow{2}{*}{$\begin{array}{l}\text { 1. Do functional disorders of the stomatognathic } \\
\text { system include pain in TMJ and/or masticatory } \\
\text { muscles? }\end{array}$} & Zagreb & $42(89.36 \%)$ & $1(2.13 \%)$ & $4(8.51 \%)$ \\
\hline & Rijeka & $21(87.50 \%)$ & & $3(12.50 \%)$ \\
\hline \multicolumn{5}{|l|}{ Fisher exact test: $\mathrm{p}=0.7911$} \\
\hline \multirow{2}{*}{$\begin{array}{l}\text { 2. Is pain in functional disorders classified } \\
\text { as musculoskeletal pain? }\end{array}$} & Zagreb & $38(80.85 \%)$ & & $9(19.15 \%)$ \\
\hline & Rijeka & $20(83.33)$ & & $4(16.67 \%)$ \\
\hline \multicolumn{5}{|l|}{ Fisher exact test: $\mathrm{p}=1.000$} \\
\hline \multirow{2}{*}{$\begin{array}{l}\text { 3. Do patients seek help and treatment mostly due to } \\
\text { TMJ pain? }\end{array}$} & Zagreb & $40(85.11 \%)$ & $2(4.26 \%)$ & $5(10.64 \%)$ \\
\hline & Rijeka & $19(79.17 \%)$ & & $5(20.83 \%)$ \\
\hline \multicolumn{5}{|l|}{ Fisher exact test: $\mathrm{p}=0.3703$} \\
\hline \multirow{2}{*}{$\begin{array}{l}\text { 4. Is prevalence of neuralgic pain in the orofacial } \\
\text { region greater in older people? }\end{array}$} & Zagreb & $21(44.68 \%)$ & $9(19.15 \%)$ & $17(36.17 \%)$ \\
\hline & Rijeka & $11(45.83 \%)$ & $2(8.33 \%)$ & $11(45.83 \%)$ \\
\hline \multicolumn{5}{|l|}{ Fisher exact test: $\mathrm{p}=0.4960$} \\
\hline \multirow{2}{*}{$\begin{array}{l}\text { 5. Is depressive mood frequent in patients } \\
\text { with chronic pain? }\end{array}$} & Zagreb & $42(89.36 \%)$ & $1(2.13 \%)$ & $4(8.51 \%)$ \\
\hline & Rijeka & $22(91.67 \%)$ & & $2(8.33 \%)$ \\
\hline \multicolumn{5}{|l|}{ Fisher exact test: $\mathrm{p}=1.000$} \\
\hline \multirow{2}{*}{$\begin{array}{l}\text { 6. Is development mechanism of acute and chronic } \\
\text { musculoskeletal pain identical? }\end{array}$} & Zagreb & $7(14.89 \%)$ & $14(29.79 \%)$ & $26(55.32 \%)$ \\
\hline & Rijeka & $5(20.83 \%)$ & $11(45.83 \%)$ & $8(33.33 \%)$ \\
\hline \multicolumn{5}{|l|}{ Fisher exact test: $\mathrm{p}=0.7077$} \\
\hline \multirow{2}{*}{$\begin{array}{l}\text { 7. Can keeping the mouth open for too long during } \\
\text { dental treatment cause symptoms in TMJs? }\end{array}$} & Zagreb & $29(61.70 \%)$ & $7(14.89 \%)$ & $11(23.40 \%)$ \\
\hline & Rijeka & $20(83.33 \%)$ & & $4(16.67 \%)$ \\
\hline \multicolumn{5}{|l|}{ Fisher exact test: $p=0.0759$} \\
\hline \multirow{2}{*}{$\begin{array}{l}\text { 8. Are anterior disc displacement and osteoarthritis } \\
\text { the most common TMDs?* }\end{array}$} & Zagreb & $25(53.19 \%)$ & $3(6.38 \%)$ & $19(40.43 \%)$ \\
\hline & Rijeka & $20(83.33 \%)$ & $1(4.17 \%)$ & $3(12.50 \%)$ \\
\hline \multicolumn{5}{|l|}{ Fisher exact test: $\mathrm{p}=0.0313^{*}$} \\
\hline \multirow{2}{*}{$\begin{array}{l}\text { 9. Is osteoarthritis of the TMJ a pathological process } \\
\text { identical to any other pathological process of joints } \\
\text { in the body? }\end{array}$} & Zagreb & $31(65.96 \%)$ & $4(8.51 \%)$ & $12(25.53 \%)$ \\
\hline & Rijeka & $19(79.17 \%)$ & $1(4.17 \%)$ & $4(16.67 \%)$ \\
\hline \multicolumn{5}{|l|}{ Fisher exact test: $\mathrm{p}=0.5085$} \\
\hline \multirow{2}{*}{$\begin{array}{l}\text { 10. Can the displacement/position of the articular disc } \\
\text { be depicted realistically by radiologic techniques? }\end{array}$} & Zagreb & $36(76.60 \%)$ & $4(8.51 \%)$ & $7(14.89 \%)$ \\
\hline & Rijeka & $19(79.17 \%)$ & $1(4.17 \%)$ & $4(16.67 \%)$ \\
\hline \multicolumn{5}{|l|}{ Fisher exact test: $\mathrm{p}=0.9103$} \\
\hline \multirow{2}{*}{$\begin{array}{l}\text { 11. Can muscular and articular disorders be } \\
\text { distinguished by clinical diagnosis? }\end{array}$} & Zagreb & $32(68.00 \%)$ & $2(4.26 \%)$ & $13(27.66 \%)$ \\
\hline & Rijeka & $18(75.00 \%)$ & $1(4.17 \%)$ & $5(20.83 \%)$ \\
\hline \multicolumn{5}{|l|}{ Fisher exact test: $\mathrm{p}=0.8078$} \\
\hline \multirow{2}{*}{$\begin{array}{l}\text { 12. Can osteoarthritic changes of articular surfaces } \\
\text { be shown by MRI? }\end{array}$} & Zagreb & $30(63.83 \%)$ & $7(14.89 \%)$ & $10(21.28 \%)$ \\
\hline & Rijeka & $17(70.83 \%)$ & $2(8.33 \%)$ & $5(20.83 \%)$ \\
\hline \multicolumn{5}{|l|}{ Fisher exact test: $\mathrm{p}=0.8095$} \\
\hline \multirow{2}{*}{$\begin{array}{l}\text { 13. Is chronic pain in the TMJ easily explained by MRI } \\
\text { finding? }\end{array}$} & Zagreb & $8(17.02 \%)$ & $16(34.04 \%)$ & $23(48.94 \%)$ \\
\hline & Rijeka & $4(16.67 \%)$ & $6(25.00 \%)$ & $14(58.33 \%)$ \\
\hline \multicolumn{5}{|l|}{$\chi^{2}$-test: $\mathrm{df} 2=4.4483 ; \mathrm{p}=0.1132$} \\
\hline 14. Is CT the best diagnostic method for osteoarthritis & Zagreb & $32(68.09 \%)$ & $1(2.13 \%)$ & $14(29.79 \%)$ \\
\hline of the TMJ? & Rijeka & $16(66.67 \%)$ & $4(16.67 \%)$ & $4(16.67 \%)$ \\
\hline
\end{tabular}


Table 2. Continued

\begin{tabular}{|c|c|c|c|c|}
\hline Question & $\begin{array}{l}\text { School of } \\
\text { Dentistry }\end{array}$ & Yes, $\mathrm{n}(\%)$ & No, n (\%) & $\begin{array}{l}\text { Do not know } \\
\mathrm{n}(\%)\end{array}$ \\
\hline \multirow{2}{*}{$\begin{array}{l}\text { 15. Do symptoms of clicking and/or crepitations in the } \\
\text { TMJ require immediate medical treatment?* }\end{array}$} & Zagreb & $17(36.17 \%)$ & $19(40.43 \%)$ & $11(23.40 \%)$ \\
\hline & Rijeka & $17(70.83 \%)$ & $2(8.33 \%)$ & $5(20.83 \%)$ \\
\hline \multicolumn{5}{|l|}{$\chi^{2}$-test: $d f 2=9.5649 ; p=0.0084^{*}$} \\
\hline \multirow{2}{*}{$\begin{array}{l}\text { 16. Do nonsteroidal antirheumatics used in the } \\
\text { treatment of temporomandibular pain increase } \\
\text { the risk of adverse effects in elderly population? }\end{array}$} & Zagreb & $18(38.30 \%)$ & $10(21.28 \%)$ & $19(40.43 \%)$ \\
\hline & Rijeka & $12(50.00 \%)$ & $4(16.67 \%)$ & $8(53.33 \%)$ \\
\hline \multicolumn{5}{|l|}{$\chi^{2}$-test: $\mathrm{df} 2=0.8963 ; \mathrm{p}=0.6388$} \\
\hline \multirow{2}{*}{$\begin{array}{l}\text { 17. Are some forms of physical therapy of the } \\
\text { stomatognathic system the method of choice?* }\end{array}$} & Zagreb & $25(53.19 \%)$ & $4(8.51 \%)$ & $18(38.30 \%)$ \\
\hline & Rijeka & $21(87.50 \%)$ & $2(8.33 \%)$ & $1(4.17 \%)$ \\
\hline \multicolumn{5}{|l|}{ Fisher exact test: $\mathrm{p}=0.0038^{*}$} \\
\hline \multirow{2}{*}{$\begin{array}{l}\text { 18. Is consulting medical specialists to be recommended } \\
\text { for patients with chronic pain? }\end{array}$} & Zagreb & $43(91.49 \%)$ & & $4(8.51 \%)$ \\
\hline & Rijeka & $22(91.67 \%)$ & $1(4.17 \%)$ & $1(4.17 \%)$ \\
\hline \multicolumn{5}{|c|}{ Fisher exact test: $p=0.5566$} \\
\hline \multirow{2}{*}{$\begin{array}{l}\text { 19. Are occlusal splints with noninvasive biomechanical } \\
\text { effects on muscles and joints advantageous in TMD } \\
\text { treatment? }\end{array}$} & Zagreb & $40(85.11 \%)$ & $2(4.26 \%)$ & $5(10.64 \%)$ \\
\hline & Rijeka & $21(87.50 \%)$ & $1(4.17 \%)$ & $2(8.33 \%)$ \\
\hline \multicolumn{5}{|l|}{ Fisher exact test: $\mathrm{p}=1.0000$} \\
\hline \multirow{2}{*}{$\begin{array}{l}\text { 20. Should patients with TMDs immediately undergo } \\
\text { prosthodontic treatment? }\end{array}$} & Zagreb & $28(59.57 \%)$ & $9(19.15 \%)$ & $10(21.28 \%)$ \\
\hline & Rijeka & $20(83.33 \%)$ & $2(8.33 \%)$ & $2(8.33 \%)$ \\
\hline
\end{tabular}

TMDs = temporomandibular disorders; TMJ = temporomandibular joint; $\mathrm{CT}=$ computed tomography; $\mathrm{MRI}=$ magnetic resonance imaging; *with significance between students of dental medicine from Zagreb and Rijeka

Table 3. Statements concerning their own opinion about geriatric dentistry education during the study (on 11-point scale (0-10) for both student subgroups)

\begin{tabular}{|l|c|}
\hline Statement & Mean \\
\hline $\begin{array}{l}\text { 1. Do you consider yourself sufficiently educated in the field of geriatric dentistry? } \\
\text { 2. Is subspecialization/postgraduate education in the field of oral health care for elderly } \\
\text { patients necessary? }\end{array}$ & 3.30 \\
\hline $\begin{array}{l}\text { 3. Should visits to geriatric centers and fieldwork in geriatric institutions be organized } \\
\text { in the course of dental studies? }\end{array}$ & 6.28 \\
\hline $\begin{array}{l}\text { 4. Have you treated a patient with special needs with respect to older age during your } \\
\text { studies? }\end{array}$ & 7.70 \\
\hline $\begin{array}{l}\text { 5. Are you satisfied with the dental skills acquired during your studies related to the care } \\
\text { for elderly patients? }\end{array}$ & $4.14^{*}$ \\
\hline $\begin{array}{l}\text { 6. Is there any danger of stigmatizing elderly patients if they are viewed exclusively } \\
\text { from the geriatric dentistry standpoint? }\end{array}$ & 6.11 \\
\hline $\begin{array}{l}\text { 7. Does the prevalence of TMDs increase with age? } \\
\text { 8. Does the psychological condition of the patient with functional disorders have } \\
\text { an important influence on the course of TMD treatment? }\end{array}$ & 6.31 \\
\hline
\end{tabular}

TMDs = temporomandibular disorders; ${ }^{*}$ with significance between students of dental medicine from Zagreb and Rijeka 
odontology; students from Zagreb had a more neutral standpoint (all answers were as follows: 'disagree/neutral standpoint/agree’: 21.28\%/44.68\%/34.04\%), whereas students from Rijeka had the most positive standpoint (29.17\%/12.50\%/58.33\%). More than half of the students from Zagreb were more unsatisfied with the skills in the field of gerodontology $(57.45 \% / 23.40 \% / 19.15 \%)$, whereas the students from Rijeka mostly provided neutral and some fewer positive answers (16.67\%/45.83\%/ $37.50 \%)$, which proved to be statistically significant ( $\chi^{2}$-test: $\left.\mathrm{df} 2=10.7410 ; \mathrm{p}=0.0047\right)$.

Regarding their opinion on the question "Does the psychological condition of the patient with functional disorders has an important influence on the course of TMD treatment?", the students from Zagreb gave the following answers: 'disagree/neutral standpoint/agree' (0.0\%/19.15\%/80.85\%). Quite different answers were provided by the students from Rijeka (8.33\%/4.17\%/ $87.50 \%)$, however, with significantly more positive statements (Fisher exact test: $\mathrm{p}=0.0394$ ) than students from Zagreb (Table 3).

\section{Discussion}

Preshaw and Mohammad ${ }^{15}$ report that a clinical component of geriatric dentistry within the curriculum was reported by $61 \%$ of dental schools, and $18 \%$ reported operating a specific geriatric dentistry clinic within the school. Dental and general health care for the elderly are gaining ever more importance as the share of elderly population, as well as the average age of the entire population increases. In Croatia, the share of elderly population was $15.62 \%$ in 2001 , to increase to $16.64 \%$ in $2004^{16}$.

In addition to topics from general gerodontology and physiology of aging, geriatric dentistry teaching includes traditional specialties as well, such as prosthodontics and implantology, which is also featured in geriatric dentistry courses in other countries ${ }^{17-19}$. Regarding the prevalence of rheumatologic diseases in the elderly, it was recognized by the students, as judged from their mostly positive answers, although it is by no means a simple fact. Since age is a major risk factor in many other chronic inflammatory diseases, it is to be expected that in elderly patients, the predominant diseases will be rheumatologic, either autoimmune by nature or a multifactorial condition for which aging is a major risk factor ${ }^{20,21}$.
The field of geriatric dentistry could be relevant to TMD patients; Ogura et al..$^{22}$ found significantly more disc displacements with osteoarthritis in $18.2 \%$ of TMD patients aged over 50 comparing with the total sample of TMD patients. In our previous study ${ }^{23}$, we recorded $22 \%$ of patients aged over 60 in the total sample of patients with TMJ disorders.

According to relevant scientific research ${ }^{24,25}$, it is not a general rule that neuralgic pain is predominant in the elderly, however, in older age, there is a significantly increased risk of developing trigeminal neuralgia after hypertension. Students should be able to differentiate neurogenic and somatic orofacial pain ${ }^{26}$. Almost half of them, particularly students from $\mathrm{Za}$ greb, did not know the difference between acute and chronic musculoskeletal pain. There is no consensus on when exactly pain becomes chronic but it certainly applies to pain lasting for more than 6 months, which is one of the factors in identifying chronic non-malignant (musculoskeletal) pain as a multidimensional experience ${ }^{27}$. Students should recognize such patients and, if necessary, refer them to a subspecialist practice. Steenks ${ }^{28}$ pointed out the great difference between scientific facts and general practice dentists' knowledge of TMD and orofacial pain.

Magnetic resonance imaging (MRI) as the gold standard in the diagnostics of arthrogenic TMD disorders still has limitations in explaining pain intensity and treatment success ${ }^{29,30}$. In our study, none of the students could determine whether MRI could explain chronic pain in TMJ.

Nonsteroidal antirheumatic drugs (NSARs) are the most commonly used medications in general, and therefore it is necessary to supervise their usage with respect to the analgesic effect achieved and their potential serious adverse drug reactions (gastrointestinal, cardiovascular, renal and hypersensitivity reactions) $)^{31,32}$. In our study, students from both groups did not consider that NASRs increased the risk of adverse effects in elderly population.

On the other hand, there was a statistically significant difference ( $\mathrm{p}=0.0313)$ in particular questions; students from Rijeka gave more positive answers than students from Zagreb on disc displacement and osteoarthritis as the most common TMJ disorders ${ }^{33}$. These are generally accepted diagnoses that can be clinically determined. Definitive diagnosis is obtained by additional MRI diagnostics, which can reduce the share of myogenic and clinically obtained wrong diagnoses ${ }^{34}$. 
Clinical significance of noise in TMJ is closely related to TMJ diagnostics ${ }^{35-40}$. TMD symptoms can be part of generalized illnesses such as secondary Sjögren's syndrome and rheumatoid polyarthritis ${ }^{35}$. In our study, students from Zagreb considered that clicking or crepitations in TMJ alone were not an obligatory indication for treatment $(\mathrm{p}=0.0084)$. Students from Zagreb had a more neutral standpoint regarding physical therapy in TMD treatment, whereas students from Rijeka gave more positive answers to this question ( $\mathrm{p}=0.0038)$. The usefulness and clinical value of physical therapy was demonstrated in a recent review of literature, although there is no universal gold standard in the treatment of TMDs ${ }^{36,37,40}$.

Both groups of students were uncertain about the fact that the prevalence of TMD decreased with age; they answered neutrally. Cooper and Kleinberg ${ }^{7}$ noted that TMDs decreased with age if the patient population was observed without differentiating particular diagnoses. Namely, the general term TMD is used very often, which leads to obscuring the suppositions of the Research Diagnostic Criteria for TMD (Axis I) usage, which enables classification of individual myogenic and/or arthrogenic diagnoses ${ }^{41-44}$. Therefore, when observing particular diagnoses, there is differentiation between disc displacement diagnosis where the mean age is closer to 30 , whereas the age peak for patients with osteoarthritis of TMJ moves to the mean age between 50 and $60^{5}$. Nevertheless, even in this subgroup of osteoarthritis diagnosis, the share of patients decreases over the age of $80^{6,9}$. There is no general attitude about the prognosis of TMD diagnoses concerning their occurrence in younger or older age. From the point of view of osteoarthritis management, it is obvious that degenerative diseases occur more often in middle and older age ${ }^{5}$.

Osteoporosis and tooth loss are health problems that affect older population, especially women. Routine $\mathrm{x}$-ray imaging is the simplest method of bone density determination. However, in some cases, even $60 \%$ of bone mass loss is needed for the naked eye to see these bone changes on a standard radiograph ${ }^{45,46}$. The risk of developing bisphosphonate-related osteonecrosis of the jaw in osteoporosis (BRONJ) patients treated with bisphosphonates (BPs) is estimated as one event per 20,000 to 100,000 patient-years. Tooth extraction, which can be an osteonecrosis trigger, is the main dental procedure associated with BRONJ. The most common amino-BPs associated with $\mathrm{BRONJ}$ are pamidronate and zoledronate, followed by ibandronate or alendronate ${ }^{47}$.

Students from Rijeka showed better knowledge of the current diagnostic procedures, wherein psychological condition could have an important influence on the treatment of TMD ( $\mathrm{p}=0.0394)$. The psychological factor has a constant impact on chronic pain, which should be taken into account when planning multidisciplinary medical collaboration. Since more than $90 \%$ of students from both groups considered that for chronic pain it is recommended to consult medical specialists, it is obvious that the students did not fully grasp the study topics ${ }^{6}$.

In order to upgrade the quality of courses at the Schools of Dental Medicine in Zagreb and Rijeka, there should be more practical teaching. However, since it is an obligatory course at the School of Dental Medicine in Rijeka, the students there showed better knowledge than the students from Zagreb. The confidence that dental students in Croatia showed through their knowledge about the diagnosis and treatment of elderly patients and their orofacial pain problems should be strengthened by a clinical component of geriatric dentistry.

\section{Acknowledgment}

This study was carried out within the frame of the project entitled Orofacial Pain and Temporomandibular Disorders - A Long Term Follow-up, University of Zagreb, Zagreb.

\section{References}

1. Mohammad AR, Preshaw PM, Ettinger RL. Current status of predoctoral geriatric education in U.S. dental schools. J Dent Educ. 2003;67:509-14.

2. De Boever JA, Nilner M, Orthlieb JD, Steenks MH; Educational Committee of the European Academy of Craniomandibular Disorders. Recommendations by the EACD for examination, diagnosis, and management of patients with temporomandibular disorders and orofacial pain by the general dental practitioner. J Orofac Pain. 2008;22:268-78.

3. Cooper BC; International College of Cranio-Mandibular Orthopedics (ICCMO). Temporomandibular disorders: a position paper of the International College of Cranio-Mandibular Orthopedics (ICCMO). Cranio. 2011;29:237-44. doi: 10.1179/crn.2011.034 
4. Badel T, Kocijan Lovko, S, Zadravec, D. Anxiety and temporomandibular disorders: a relationship in chronic pain development. In: Shiloh AR, ed. Anxiety Disorders - Risk Factors, Genetic Determinants and Cognitive-Behavioral Disorders. New York: Nova Science Publishers, 2014. pp.93-123.

5. Manfredini D, Piccotti F, Ferronato G, Guarda-Nardini L. Age peaks of different RDC/TMD diagnoses in a patient population. J Dent. 2010;38:392-9. doi: 10.1016/j.jdent.2010.01.006

6. Schmitter M, Rammelsberg P, Hassel A. The prevalence of signs and symptoms of temporomandibular disorders in very old subjects. J Oral Rehabil. 2005;32:467-73. doi: 10.1111/ j.1365-2842.2005.01449.x

7. Cooper BC, Kleinberg I. Examination of a large patient population for the presence of symptoms and signs of temporomandibular disorders. Cranio. 2007;25:114-26. doi: 10.1179/crn. 2007.018

8. Klasser GD, Greene CS. The changing field of temporomandibular disorders: what dentists need to know? J Can Dent Assoc. 2009;75:49-53.

9. Sandler N, Ziccardi V, Ochs M. Differential diagnosis of jaw pain in the elderly.J Am Dent Assoc. 1995;126:1263-70.

10. Türp JC, Jokstad A, Motschall E, Schindler HJ, WindeckerGétaz I, Ettlin DA. Is there a superiority of multimodal as opposed to simple therapy in patients with temporomandibular disorders? A qualitative systematic review of the literature. Clin Oral Implants Res. 2007;18(Suppl 3):138-50. doi: 10.1111/j.1600-0501.2007.01480.x

11. Burris JL, Evans DR, Carlson CR. Psychological correlations of medical comorbidities in patients with temporomandibular disorders. J Am Dent Assoc. 2010;141:22-31. doi: 10.14219/ jada.archive.2010.0017

12. Von Korff M, Dunn KM. Chronic pain reconsidered. Pain. 2008;138:267-76. doi: 10.1016/j.pain.2007.12.010

13. Glaros AG, Glass EG, McLaughlin L. Knowledge and beliefs of dentists regarding temporomandibular disorders and chronic pain. J Orofac Pain. 1994;8:216-22.

14. Kern J. Medicinsko-informatičke metode. Zagreb: Medicinska naklada, 2004. (in Croatian)

15. Preshaw PM, Mohammad AR. Geriatric dentistry education in European dental schools. Eur J Dent Educ. 2005;9:73-7. doi: 10.1111/j.1600-0579.2004.00357.x

16. Murgić J, Jukić T, Tomek-Roksandić S, Ljubičić M, Kusić Z. The ageing of Croatian population. Coll Antropol. 2009;33: 701-5.

17. Vallon D, Nilner M. Undergraduates' and graduates' perception of achieved competencies in temporomandibular disorders and orofacial pain in a problem-based dental curriculum in Sweden. Eur J Dent Educ. 2009;13:240-7. doi: 10.1111/j.1600-0579. 2009.00583.x

18. Tegelberg A, Wenneberg B, List T. General practice dentists' knowledge of temporomandibular disorders in children and adolescents. Eur J Dent Educ. 2007;11:216-21. doi: 10.1111/ j.1600-0579.2007.00458.x
19. Ommerborn MA, Kollmann C, Handschel J, Depprich RA, Lang H, Raab WH. A survey on German dentists regarding the management of craniomandibular disorders. Clin Oral Investig. 2010;14:137-44. doi: 10.1007/s00784-009-0282-4

20. Glibotić Kresina H, Kresina S, Gašparović Babić S, Rončević $\mathrm{D}$, Dadić Hero E, Ružić K, et al. Anxiety disorders in elderly in primary care of Primorsko-goranska County. Period Biol. 2013;115:553-9.

21. Tomek Roksandić S, Tomasović Mrčela N, Smolej Narančić N, Šostar Z, Lukić M, et al. Gerontology public health management in Croatia. Period Biol. 2013;115:469-74.

22. Ogura I, Kaneda T, Mori S, Sakayanagi M, Kato M. Magnetic resonance characteristics of temporomandibular joint disc displacement in elderly patients. Dentomaxillofac Radiol. 2012; 41:122-5. doi: $10.1259 / \mathrm{dmfr} / 1286942$

23. Badel T, Kraljević Šimunković S, Marotti M, Kocijan Lovko S, Kern J, Krolo I. Study of temporomandibular joint disorder in older patients by magnetic resonance imaging. Gerodontology. 2012;29:735-41. doi: 10.1111/j.1741-2358.2011.00552.x

24. Pan SL, Yen MF, Chiu YH, Chen LS, Chen HH. Increased risk of trigeminal neuralgia after hypertension: a populationbased study. Neurology. 2011;77:1605-10. doi: 10.1212/WNL. 0b013e3182343354

25. Mueller D, Obermann M, Yoon MS, Poitz F, Hansen N, Slomke MA, et al. Prevalence of trigeminal neuralgia and persistent idiopathic facial pain: a population-based study. Cephalalgia. 2011;31:1542-8. doi: 101177/0333102411424619

26. Badel T, Savić Pavičin I, Bašić Kes V, Zavoreo I, Zadravec D, Kern J. Comparison of patients with orofacial pain caused by trigeminal neuralgia and/or temporomandibular joint disorder. Swiss Arch Neurol Psychiatry. 2013;164 (Suppl 6):22S [Abstract]. http://www.sanp.ch/docs/sanp/archiv/pdf/2013/ SANP_Suppl_6.pdf

27. Badel T, Dulčić N, Zadravec D, Rosić D, Kocijan Lovko S. Angst bei Patienten mit Kiefergelenkarthrose. Deutscher Schmerzkongress 2014, Hamburg, Oct 22-25, 2014. Schmerz. 2014;28 (Suppl 1):87-8. [Abstract]. (in German)

28. Steenks MH. The gap between dental education and clinical treatment in temporomandibular disorders and orofacial pain. J Oral Rehabil. 2007;34:475-7. doi: j.1365-2842.2007.01711.x

29. Laškarin M, Badel T, Kern J, Savić Pavičin I, Zadravec D. Metric evaluation of partially displaced temporomandibular joint disc. Acta Clin Croat. 2014;53:310-8.

30. Jerolimov V. Temporomandibular disorders and orofacial pain. Rad 504 Medical sciences 2009;33:53-77.

31. Marini I, Bartolucci ML, Bortolotti F, Gatto MR, Bonetti GA. Palmitoylethanolamide versus a nonsteroidal anti-inflammatory drug in the treatment of temporomandibular joint inflammatory pain. J Orofac Pain. 2012;26:99-104.

32. BadelT, Rošin-Grget K, Krapac L, Marotti, M. Principi farmakoterapije temporomandibularnih poremećaja. Medicus. 2007; 16:241-50. (in Croatian) 
33. Badel T, Simonić-Kocijan S, Lajnert V, Dulčić N, Zadravec D. Michigan splint and treatment of temporomandibular joint review of literature. Medicina Fluminensis. 2013;49:112-20.

34. Ladeira DB, Cruz AD, Almeida SM. Digital panoramic radiography for diagnosis of the temporomandibular joint: CBCT as the gold standard. Braz Oral Res. 2015;29:1-7. doi: 10.1590/1807-3107BOR-2015.vol29.0120

35. Krapac L, Badel T. Disorder of temporomandibular joint - a rheumatological and physiatric approach. Rad HAZU Medicinske znanosti 2010;34:97-109.

36. Badel T, Krapac K, Savić Pavičin I, Kocijan Lovko S, Kern, Zadravec D. Physical therapy with topical ketoprofen and anxiety related to temporomandibular joint pain treatment. Fiz Rehabil Med. 2013;25:6-16.

37. Badel T, Savić Pavičin I, Čimić S, Zadravec D. Diagnostics and management of temporomandibular joint disorder - a reported case with a review of literature. J Dent Probl Solut. 2016;3: 018-023. doi: 10.17352/2394-8418.000027

38. Badel T, Savić Pavičin I, Jakovac M, Kern J, Zadravec, D. Disc and condylar head position in the temporomandibular joint with and without disc displacement. Coll Antropol. 2013; 37:901-6.

39. Badel T, Savić Pavičin I, Bašić Kes V, Zavoreo I, Zadravec D, Kern J. Orofacial pain caused by trigeminal neuralgia and/or temporomandibular disorders. Period Biol. 2013;115:185-9.

40. Čimić S, Kraljević Šimunković S, Simonić Kocijan S, Matijević J, Dulčić N, Ćatić A. Articulator-related registration and analysis of sagittal condylar inclination. Acta Clin Croat. 2015; $54: 432-7$
41. Türp JC. Diagnostic criteria for temporomandibular disorders (DC/TMD) - presentation of the Axis I classification. J Craniomandib Funct. 2014;6:213-9.

42. Türp JC, Schlenker A, Schröder J, Essig M, Schmitter M. Disk displacement, eccentric condylar position, osteoarthrosis - misnomers for variations of normality? Results and interpretations from an MRI study in two age cohorts. BMC Oral Health. 2016 Nov 17;16:124. doi: 10.1186/s12903-016-0319-4

43. Schiffman E, Ohrbach R, Truelove E, Look J, Anderson G, Goulet JP, et al. Diagnostic Criteria for Temporomandibular Disorders (DC/TMD) for Clinical and Research Applications: recommendations of the International $\mathrm{RDC} / \mathrm{TMD}$ Consortium Network and Orofacial Pain Special Interest Group. J Oral Facial Pain Headache. 2014;28:6-27.

44. Šečić A, Cvjetičanin T, Bašić Kes V. Biofeedback training and tension-type headache. Acta Clin Croat. 2016;55:156-60.

45. Pavičin IS, Dumančić J, Badel T, Vodanović M. Timing of emergence of the first primary tooth in preterm and full-term infants. Ann Anat. 2016;pii:S0940-9602(15)00078-3. doi: 10.1016/j.aanat.2015.05.004

46. Savić Pavičin I, Dumančić J, Jukić T, Badel T, Badanjak A. Digital orthopantomograms in osteoporosis detection: mandibular density and mandibular radiographic indices as skeletal BMD predictors. Dentomaxillofac Radiol. 2014;43(7): 20130366. doi: 10.1259/dmfr.20130366

47. Badel T, Savić Pavičin I, Jelinić Carek A, Rošin Grget K, Grbeša Đ. Pathophysiology of osteonecrosis of the jaw in patients treated with bisphosphonate Coll Antropol. 2013;37: 645-51.

Sažetak

\section{ZNANJE DODIPLOMSKIH STUDENATA IZ HRVATSKE O TEMPOROMANDIBULARNIM POREMEĆAJIMA}

\section{T. Badel, I. Bago Jurič, V. Fugošić, I. Zajc, A. Carek i D. Zadravec}

Svrha istraživanja bila je procijeniti znanje hrvatskih dodiplomskih studenata o temporomandibularnim poremećajima (TMP) u starijih osoba, kao i njihova vlastita prosudba i mišljenje o izobrazbi iz gerontostomatologije koju uče u sadašnjim kolegijima. Istraživanje je provedeno pomoću upitnika kod studenata posljednje godine studiranja na Stomatološkom fakultetu Sveučilišta u Zagrebu i na Studiju stomatologije Medicinskog fakulteta Sveučilišta u Rijeci. Upitnik je sadržavao pitanja o važnom specifičnom znanju o TMP, kao i stajališta vezana za vlastito mišljenje o izobrazbi iz gerontostomatologije tijekom studiranja. Vezano za znanje studenata o TMP, studenti iz Rijeke dali su više pozitivnih odgovora $(\mathrm{p}=0,012)$. Studenti iz Rijeke dali su više pozitivnih odgovora vezanih za fizikalnu terapiju u liječenju TMP $(\mathrm{p}=0,004)$ te za pomak diska i osteoartritis kao najčešćih poremećaja čeljusnog zgloba ( $\mathrm{p}=0,031$ ). Studenti iz Zagreba bili su nezadovoljniji (nezadovoljnih 57,45\%) nego studenti iz Rijeke (45,83\% ih je imalo neutralno stajalište i 37,50\% ih je bilo zadovoljno) vještinama iz područja gerontostomatologije $(\mathrm{p}=0,005)$. Razina znanja sudionika istraživanja pokazala je da je važno unaprijediti dodiplomsku nastavu stomatologije sa specifičnom gerijatrijskom izobrazbom koja uključuje znanje o TMP.

Ključne riječi: Studenti; Hrvatska; Gerontostomatologija; Osteoartritis; Temporomandibularni zglob, poremé́aji; Edukacija, stomatološka 